\title{
PELATIHAN PEMBUATAN ALAT PENANGKAPAN IKAN RAMAH LINGKUNGAN
}

\author{
Mustasim $^{1 *}$, Endang Gunaisah ${ }^{2}$, M. Ali Ulat ${ }^{3}$, Handayani ${ }^{4}$, Ismaili5, Amir M \\ Suruwaky ${ }^{6}$, Misbah Sururi ${ }^{7}$, Vicky Rizky Affandy Katilii, Hendra Poltak ${ }^{9}$ \\ 1,2,3,4,5,6,7,8,9 Politeknik Kelautan dan Perikanan Sorong, Sorong, Indonesia \\ *Penulis Koresponsensi, email: mustasim@polikpsorong.ac.id
}

Received:21/01/2021

Revised:16/02/2021

Accepted:18/02/2021

\begin{abstract}
Destructive fishing has the potential to reduce the sustainability of marine resources and the productivity of marine products which will have an impact on the welfare of fishermen. Various motives for destructive fishing include economic, social, cultural motives, and even ignorance that this action is against the law. Politeknik Kelautan dan Perikanan Sorong carries out community service as an effort to provide understanding regarding environmentally friendly fisheries through lectures and the practice of making environmentally friendly fishing gear. The activity lasted for 2 days, attended by 20 fishermen target partners of Saoka Village. The results of the practice in the form of environmentally friendly fishing gear are handed over to target partners for use in fishing operations.
\end{abstract}

Keywords: Fishing Gear; Community Service; Fishing; Environmentally Friendly.

\begin{abstract}
Abstrak. Penangkapan ikan tidak ramah lingkungan berpotensi mengurangi kelestarian sumber daya laut dan produktivitas hasil laut yang akan berdampak kepada kesejahteraan nelayan. Berbagai motif terjadinya Penangkapan ikan tidak ramah lingkungan diantaranya motif ekonomi, sosial, budaya, bahkan ketidaktahuan bahwa tindakan tersebut merupakan perbuatan melawan hukum. Politeknik Kelautan dan Perikanan Sorong melaksanakan pengabdian masyarakat sebagai upaya memberikan pemahaman terkait perikanan ramah lingkungan melalui ceramah dan praktik pembuatan alat tangkap ramah lingkungan. Kegiatan berlangsung selama 2 hari, diikuti oleh 20 mitra sasaran nelayan kelurahan Saoka. Hasil praktik berupa alat tangkap ramah lingkungan diserahkan kepada mitra sasaran untuk digunakan dalam operasi penangkapan ikan.
\end{abstract}

Kata Kunci: Alat Tangkap; Pengabdian Masyarakat; Penangkapan Ikan ; Ramah Lingkungan.

How to Cite: Mustasim, M., Gunaisah, E., Ulat, M. A., Handayani, H., Ismail, I., Suruwaky, A. M. ., Sururi, M., Katili, V. R. A. ., \& Poltak, H. (2021). PELATIHAN PEMBUATAN ALAT PENANGKAPAN IKAN RAMAH LINGKUNGAN. Mitra Mahajana: Jurnal Pengabdian Masyarakat, 2(1), 41-48. https://doi.org/10.37478/mahajana.v2i1.799

\section{PENDAHULUAN}

Praktik penangkapan ikan yang merusak lingkungan berpotensi mengurangi sumber daya keanekaragaman hayati dan menurunkan produktivitas ekosistem laut yang tentu akan berdampak kepada penghasilan masyarakat nelayan yang menggantungkan hidupnya pada lingkungan ekosistem laut (Gray, 2010). Praktik desctructive ini juga masih terjadi di beberapa wilayah di Indonesia, tidak terkecuali di wilayah kota Sorong. Oknum masyarakat menggunakan alat tangkap yang tidak ramah lingkungan seperti bom, bius, potassium, dan alat tangkap yang merusak seperti trawl.

Kelurahan Saoka terletak di ujung barat kota Sorong. Wilayahnya adalah wilayah yang terbentang disepanjang pesisir yang langsung berhadapan dengan samudera pasifik. Kelurahan yang berjarak $14 \mathrm{Km}$ ke pusat kota Sorong ini memiliki luas wilayah $50.83 \mathrm{~km}^{2}$ dan jumlah penduduk sebanyak 1.984 jiwa, sebagian besar penduduk berprofesi sebagai nelayan, petani, dan pedagang (Maladum Mes dalam Angka, 2019).

Potensi geografis kelurahan Saoka yang memilik ekosistem laut beraneka ragam sumber daya hayati ekonomis tinggi ini tentunya merupakan berkah bagi masyarakat yang berdiam di wilayah pesisir yang menjadikan ekosistem sebagai sumber mata pencaharian. Namun, potensi ini harus dapat diseimbangkan dengan mempertahankan hasil ekonomi dan ekologi (Martinet 
et al., 2015). Hal ini menunjang penyelenggaraan pembangunan dengan menerapakan prinsipprinsip pembangunan berkelanjutan di Papua Barat sebagai provinsi Konservasi (Perdasus, 2019)

Tim pengabdian masyarakat melakukan pengamatan langsung untuk memperoleh gambaran motif masyarakat yang melakukan destructive fishing. Destructive Fishing ini dilakukan dengan cara mencampurkan bahan kimia sebagai bahan peledak untuk memperoleh hasil tangkap (Bubun dan Anwar, 2016). Hasil pengamatan yang dilakukan bahwa motif melakukan desctrutive fishing antara lain sosial, sosial ekonomi, demografi, dan sosial budaya (Lampe et al., 2017), disamping adanya ketidaktahuan masyarakat bahwa melakukan tindakan destructive fishing merupakan tindakan melawan hukum dan menggangu keberlanjutan perikanan di masa yang akan datang.

Politeknik KP Sorong sebagai Lembaga Pendidikan turut bertanggung jawab terhadap keberlanjutan lingkungan dan membantu menjalankan program pemerintah sesuai dengan Perdasus Nomor 10 Tahun 2019 sesuai dengan misi utama Kementerian Kelautan dan Perikanan untuk menciptakan perikanan yang berkelanjutan. Peran Politeknik sesuai dengan tugas dan fungsinya melakukan penelitian dan pengabdian masyarakat terkhusus dibidang Kelautan dan Perikanan. Pengabdian masyarakat yang dilakukan oleh politeknik KP Sorong berupaya memberikan edukasi kepada masyarakat sehingga masyarakat selain mematuhi aturan yang ada, juga ada alternatif usaha yang dilakukan untuk tetap menjaga eksistensi mata pencahariannya untuk menghidupi keluarga dan bahkan meningkatkan kesejahteraannya.

Edukasi untuk keberlanjutan perikanan dalam bentuk kegiatan pengabdian masyarakat. Santosa et al (2019) memberikan pemberdayaan nelayan tangkap tradisional melalui penggunaan alat bantu pengumpul ikan ramah lingkungan. Pengenalan alat tangkap bubu rangka besi untuk menangkap kepiting di kampung Beeng memberikan wawasan baru bagi nelayan menangkap kepiting bakau tanpa merusak lingkungan (Kaim et al., 2017). Dewanti et al (2018) menyatakan penyuluhan prinsip penangkapan ikan ramah lingkungan mengunggah komitmen dan pengetahuan baru untuk menghindari penangkapan destructive dan organisme yan dilarang pada pengabdian masyarakat di Pangandaran. Program pemakaian alat tangkap ramah lingkungan diaplikasikan oleh nelayan kabupaten Pangkep (Jompa et al., 2018).

\section{METODE PELAKSANAAN}

Mitra sasaran yang akan dilakukan pengabdian masyarakat diberikan peningkatan pengetahuan dan keterampilannya. Peningkatan pengetahuan dilakukan dengan metode ceramah melalui penyampaian teori yang diperkaya dengan diskusi dan tanya jawab. Metode ceramah dengan Teknik pengaktifan peserta melalui tanya jawab dan diskusi akan memotivasi peserta untuk memahami dan menguasai materi yang diberikan (Mujiman, 2006). Metode pelatihan dengan praktik yaitu memandu peserta untuk memperagakan dengan contoh konkrit dari materi ceramah yang telah dilaksanakan untuk menyelesaikan permasalahan mitra. Metode ceramah dan praktik yang disepakati oleh mitra dan tim pengabdian adalah :

Tabel 1. Materi Pengabdian Masyarakat

\begin{tabular}{clc}
\hline No & \multicolumn{1}{c}{ Materi } & Metode \\
\hline 1 & Perikanan Ramah Lingkungan & Ceramah Teori \\
\hline 2 & Keselamatan Dasar Nelayan & Ceramah Teori \\
\hline 3 & Merakit Alat Tangkap Gillnet dan Pancing Cumi & Ceramah Teori dan Praktik \\
\hline 4 & Pengoperasian Gillnet dan Pancing Cumi & Ceramah Teori dan Praktik \\
\hline 5 & Perbaikan dan Perawatan Alat Tangkap Gillnet dan Pancing & Cermah teori dan Praktik \\
& Cumi & \\
\hline
\end{tabular}

Metode ceramah dilaksanakan di lokasi praktik yang diikuti oleh seluruh mitra sasaran. Tim pengabdi melakukan pembagian kelompok peserta untuk mengefektifkan hasil pelatihan 
melalui kegiatan praktik. Kegiatan praktik berlangsung di unit pelaksanan praktik (UPK) fishing gear dengan pendampingan oleh dosen pengabdi dan instruktur teknik penangkapan ikan.

Kegiatan pengabdian masyarakat berlangsung selama dua hari, tanggal 16 s.d 17 Juli 2019. Pelatihan diikuti oleh 20 peserta dari perwakilan kelompok nelayan kelurahan Saoka, kota Sorong.

\section{HASIL DAN PEMBAHASAN}

\section{Materi Teori}

Ceramah teori materi pertama yang disampaikan adalah materi perikanan yang bertanggung jawab. Materi awal ini memberikan pemahaman kepada mitra sasaran pentingnya mitra sasaran mengetahui perikanan yang bertanggung jawab. Pemateri berupaya memberikan materi yang menyadarkan bahwa nelayan merupakan sosok kunci untuk memastikan keberlanjutan sumber daya ikan dan ketersediaanya ikan untuk diwariskan kepada anak cucu. Mussadun et al., (2011) menyatakan bahwa dukungan dari nelayan merupakan kunci keberhasilan manajemen perikanan yang berkelanjutan.

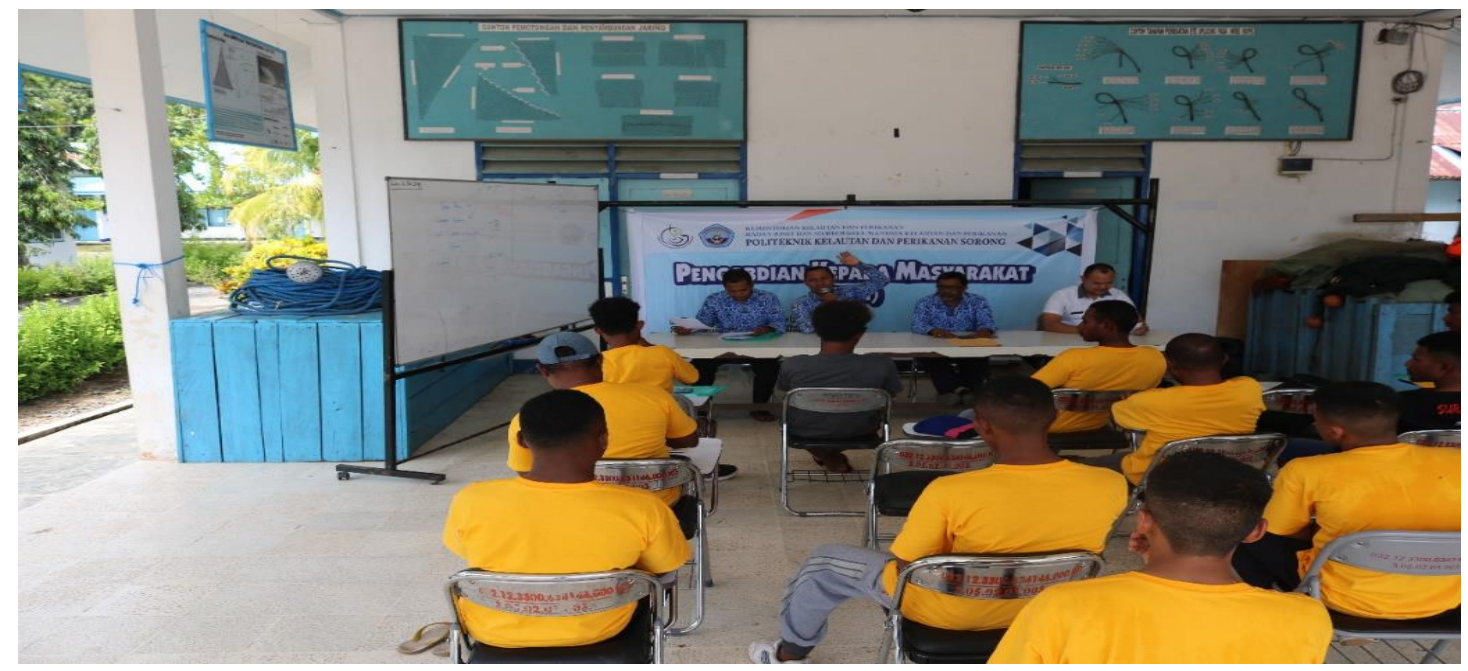

Gambar 1. Penyampaian Materi Ceramah Perikanan Ramah Lingkungan

Pemahaman selanjutnya, mitra diberikan aturan-aturan yang mendukung pelaksanaan penangkapan ikan yang bertanggung jawab untuk dapat dipatuhi dan dijalankan oleh nelayan dalam melaksanakan pekerjaannya sehari hari. Aturan-aturan yang disampaikan oleh pemateri diantaranya adalah 9 kriteria alat tangkap ramah lingkungan sesuai Code of Conduct for Responsible Fisheries (CCRF) tahun 1995. Pemateri menyampaikan 9 kriteria alat tangkap ramah lingkungan yaitu : memiliki memiliki selektivitas yang tinggi; tidak merusak habitat, tempat tinggal dan berkembang biak organisme; tidak membahayakan nelayan (penangkap ikan); menghasilkan ikan yang bermutu baik;produk tidak membahayakan kesehatan konsumen; hasil tangkap yang terbuang minimum; alat tangkap yang digunakan harus memberikan dampak yang minimum terhadap biodivesitas; tidak menangkap jenis yang dilindungi undang-undang; diterima secara sosial. Selain menyampaikan aturan CCRF tahun 1995 pemateri juga menyampaikan aturan-aturan yang dikeluarkan oleh Pemerintah melalui Kementerian Kelautan dan Perikanan.

Pemateri menambahkan dalam paparannya terkait sifat serakah manusia yang menggunakan racun untuk mendapatkan ikan. Efek yang dilakukan manusia merupakan tindakan kejam karena ikan berjuang lama untuk melawan dan kejang dan lemas sampai mati. Selain itu, ikan yang belum saatnya ditangkap juga akan mati yang tentu akan merusak kelangsungan hidup habitat. Materi yang disampaikan semakin menarik, diakhir materi isu sumber daya manusia kelautan dan perikanan diantaranya Illegal, Unreported, and Unregulated (IUU) Fishing Global yang menyebabkan Indonesia kehilangan potensi pemasukan bagi negara. 
Potensi pemasukan itu dapat meningkatkan status gizi sdm Indonesia dan meningkatkan pendidikan lebih baik.

Laut adalah sumber kehidupan bagi nelayan, dapat juga menjadi sumber ancaman bagi kehidupan nelayan. Nelayan bekerja langsung berhadapan dengan cuaca buruk berupa gelombang besar dan kurangnya keterampilan peralatan keselamatan kerja yang berpotensi rawan menimbulkan kecelakaan kerja (Imron et al., 2017). Nelayan belum cukup memahami pengetahuan higeny dan sanitasi saat melaut menyebabkan banyaknya kecelakaan kerja di laut (Ratri dan Paskarini, 2014). "Materi pertama kelangsungan hidup sumber daya ikan, materi kedua adalah kelangsungan hidup nelayan", papar pemateri sebagai pembuka materi.

Pemaparan dilanjutkan bahwa keselamatan kerja dibutuhkan juga oleh nelayan (Hendrawan, 2017). Materi keselamatan dan bertahan di laut berupa petunjuk praktis tentang tindakan yang harus dilakukan pada saat terjadinya kecelakaan. Kecelakaan dilaut dimaksud seperti terbakarnya kapal; tabrakan dengan kapal lain, benda di laut; kapal kandas atau terdampar; kebocoran; dan tenggelam.

Materi keselamatan dasar yang diberikan juga dihadiri oleh Lurah Saoka yang sekaligus menerima life jacket sebagai bagian dari sinergi kelurahan dan politeknik dalam memberdayakan nelayan. Life jacket nantinya akan diberikan kepada nelayan di akhir acara untuk dapat dipakai nelayan pada saat melaut.

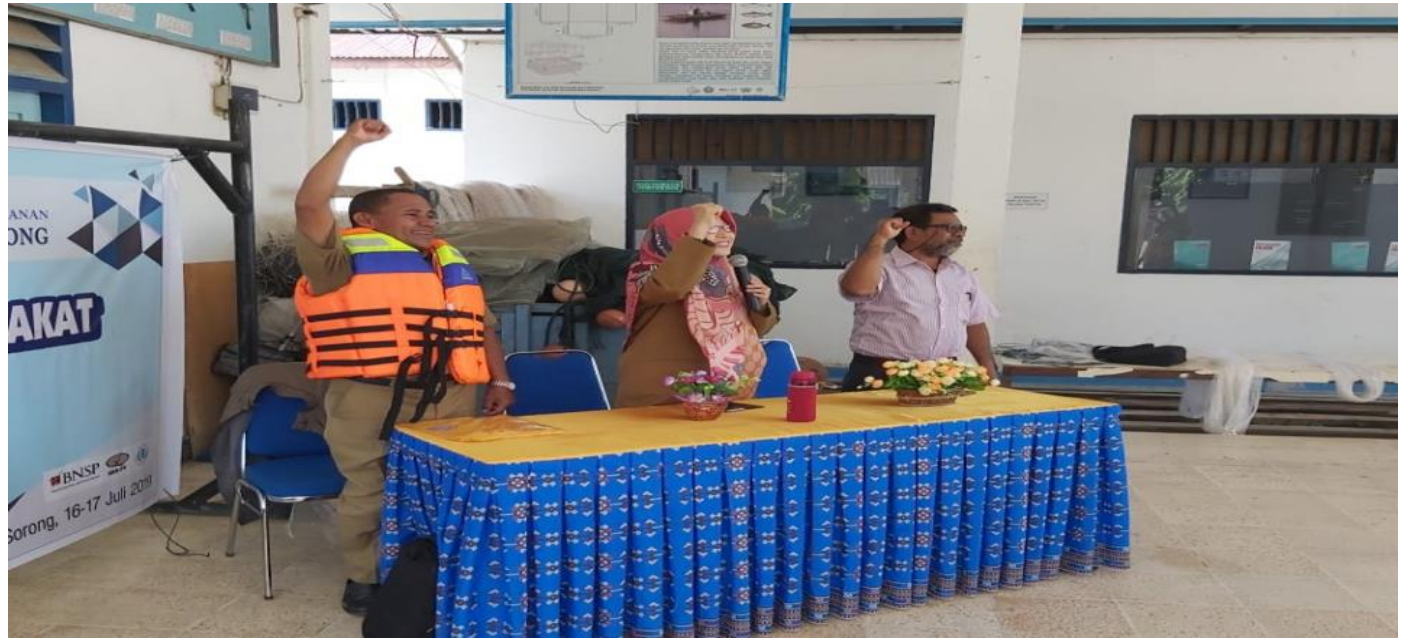

Gambar 2. Pemberian Materi Keselamatan Dasar Nelayan

Sesi tanya jawab dan diskusi diberikan setelah materi perikanan ramah lingkungan dan keselamatan dasar nelayan selesai dipaparkan. Antusias mitra sasaran untuk dapat lebih memahami materi yang disampaikan melalui pertanyaan dan diskusi. Pertanyaan-pertanyaan yang disampaikan dijawab melalui diskusi untuk mengaktifkan peserta yang mengikuti kegiatan dan diskusi tuntas menjawab pertanyaan-pertanyaan yang diajukan.

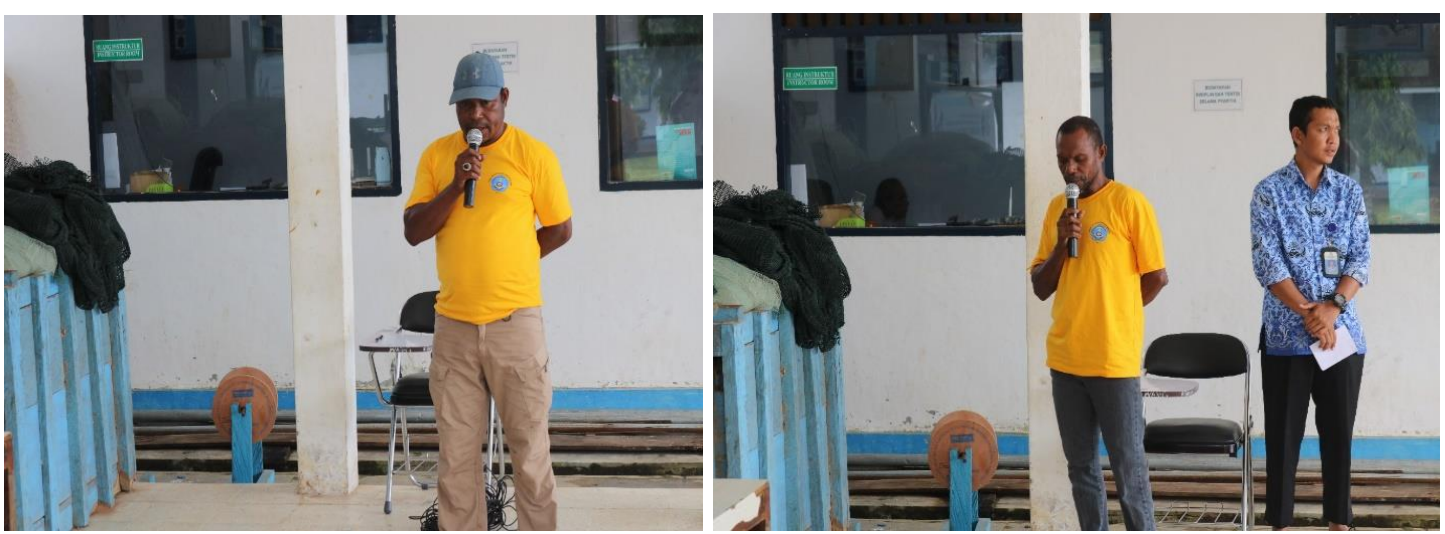

Gambar 3. Sesi Tanya Jawab Dengan Mitra Sasaran 


\section{Materi Keterampilan}

Tindak lanjut perikanan ramah lingkungan dalam pengabdian masyarakat ini adalah pembuatan alat tangkap ramah lingkungan. Alat penangkap ikan (API) yang ramah lingkungan memenuhi kriteria merupakan API yang dioperasikan tidak mengancam kepunahan biota; mengakibatkan kehancuran habitat; dan membahayakan keselamatan penggunan (Permen KP 71, 2017). Gillnets merupakan API yang diperbolehkan untuk digunakan oleh menangkap ikan (Subehi et al., 2017). Gillnet memenuhi kriteria CCRF (Sumardi et al., 2014). Istilah Gillnets didasarkan pada pemikiran bahwa ikan-ikan yang tertangkap terjerat di sekitar operculum pada mata jaring (Sutrisno et al., 2014).

Teori alat tangkap ramah lingkungan yang telah disampaikan oleh pemateri adalah pengenalan gambar dan bentuk alat penangkapan ikan baik yang tidak ramah lingkungan maupun yang ramah lingkungan sehingga mitra mengenal semua alat tangkap. Teori selanjutnya dirangkai dengan praktik pembuatan alat pancing Gillnets dan pancing cumi. Pemilihan praktik ini disesuaikan dengan karakteristik nelayan kelurahan Saoka. Praktik pembuatan alat pancing Gillnets dan pancing cumi dilakukan secara berkelompok. Satu kelompok pelatihan terdiri dari 5 nelayan dipandu oleh seorang instruktur. Praktik dimulai dari mendesaing alat tangkap, menyiapkan kebutuhan peralatan dan bahan, hingga merangkai komponen alat tangkap.

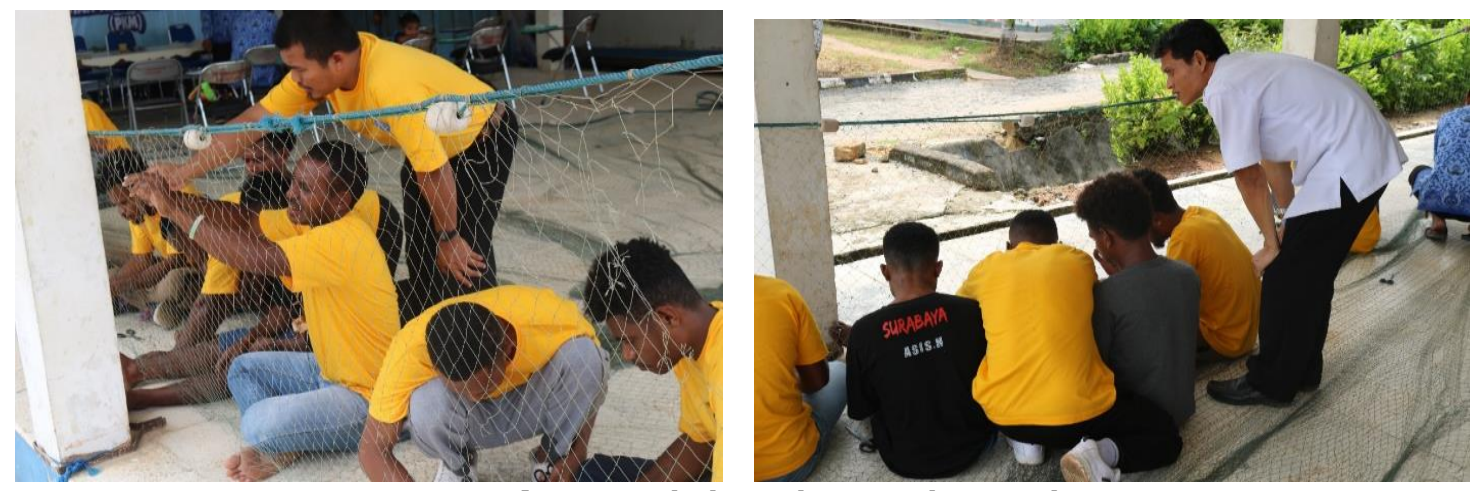

Gambar 4. Praktik Pembuatan Alat Tangkap

Hasil praktik pembuatan alat tangkap Gillnets dan pancing cumi ini selanjutnya disimulasikan untuk dioperasikan. Simulasi pengoperasian dilakukan langsung oleh dosen pengabdi dan diikuti oleh mitra sasaran. Simulasi berupa mempersiapkan perbekalan maupun logistik yang dibutuhkan pada saat operasi penangkapan ikan, menentukan lokasi atau daerah penangkapan ikan, mempersiapkan alat tangkap yang digunakan, serta menentukan jenis ikan sasaran (Amin et al., 2018). Tim pengabdi dan instruktur melakukan penilaian terhadap cara pengoperasian alat tangkap yang tepat yang disimulasikan oleh mitra sasaran.

Alat tangkap sebagai modal usaha nelayan pasti mengalami penyusutan. Penyusutan alat tangkap terjadi karena usia pakai pakai alat tangkap tersebut. Kemampuan melakukan perawatan sederhana terhadap alat tangkap mempu menambah usia pakai alat penangkap ikan. Hal ini tentunya akan menguntungkan nelayan karena akan mengurangi beban operasional nelayan.

Praktik perbaikan dan perawatan alat tangkap gilnet dan pancing cumi ini dimaksudkan untuk memberikan ketrampilan bagi nelayan. Kemampuan melakukan perawatan dan perbaikan alat tangkap untuk meningkatkan kemandirian dan keberdayaan dalam mengelola alat penangkapan ikan.

Mitra sasaran diberikan praktik cara menyimpan alat penangkap ikan yang baik. Cara yang dipraktikkan dalam kegiatan pengabdian masyarakat tersebut yaitu : mencegah kerusakan akibat kontaminasi dengan bahan penyamak nabati, hewani, maupun kimia; dan 
teknik strelisasi dengan cara menjemur alat penangkap ikan pada sinar matahari untuk membunuh organisme yang melekat pada alat penangkap ikan.

Tim pengabdi melakukan evalusi akhir hasil praktik akhir selama 2 hari kegiatan berlangsung. Hasil evaluasi menjadi indikator keberhasilan kegiatan pengabdian masyarakat. Evalusi dapat dilihat pada Tabel 2. :

Tabel 2. Evaluasi hasil kegiatan

\begin{tabular}{clc}
\hline No & Nama Praktik & Hasil \\
\hline 1. & Merakit Alat Tangkap Gillnets dan Pancing Cumi & \\
& & $\begin{array}{c}\text { 20 peserta dapat melakukan } \\
\text { praktik dengan hasil baik }\end{array}$ \\
\hline 2. & Pengoperasian Gillnets dan Pancing Cumi & 20 peserta dapat melakukan \\
& & praktik dengan hasil baik \\
\hline 3. & Perbaikan dan Perawatan Alat Tangkap Gillnet dan Pancing & 20 peserta dapat melakukan \\
& Cumi & praktik dengan hasil baik \\
\hline
\end{tabular}

Politeknik Kelautan dan Perikanan melalui tim pengabdian masyarakat memberikan bantuan alat penangkapan ikan ramah lingkungan hasil praktik kepada mitra sasaran. Bantuan lain yang diberikan adalah life jacket sebagai bekal nelayan dalam menjalankan profesinya menangkap ikan di laut. Bantuan diberikan oleh tim pengabdi disaksikan oleh Lurah Saoka dan penyuluh perikanan wilayah kelurahan Saoka. Bantuan tersebut diharapkan dapat mendorong produktifitas nelayan dalam menangkapan ikan menggunakan alat tangkap ramah lingkungan serta meningkatka rasa aman bagi nelayan beraktivitas.

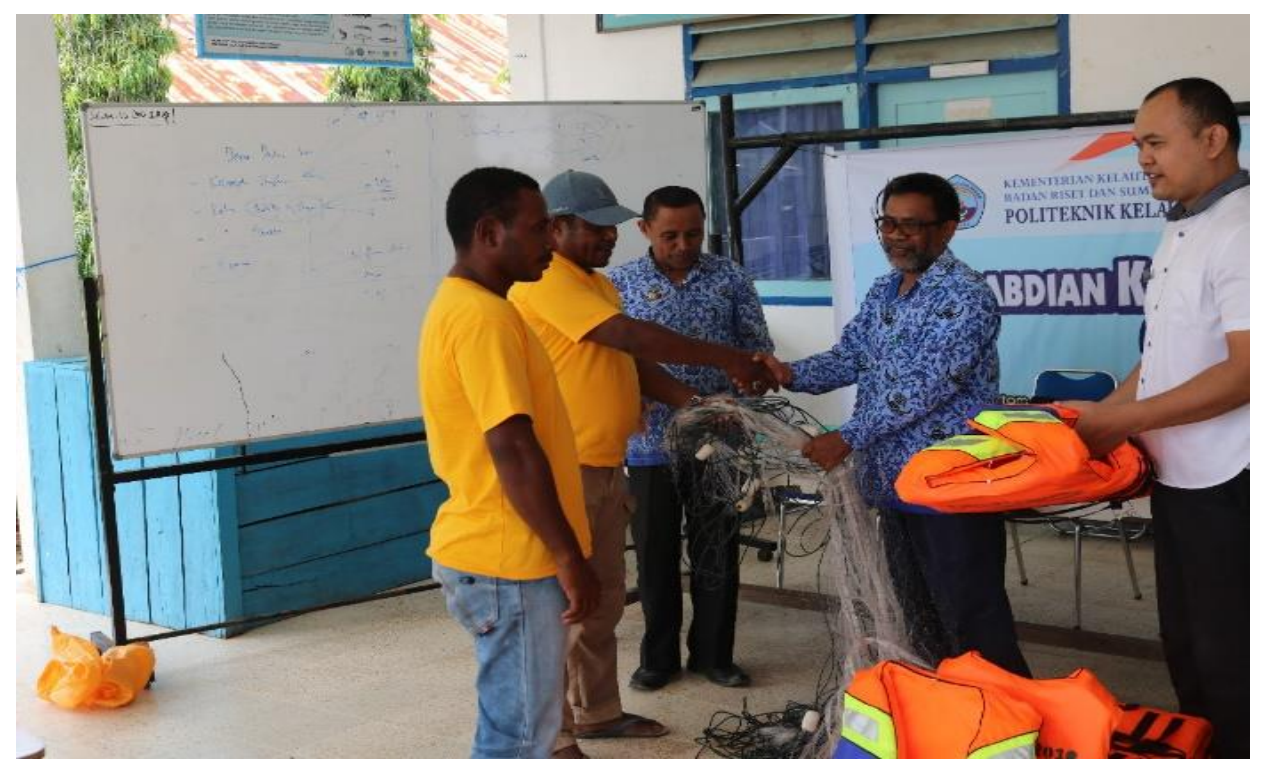

Gambar 5. Pemberian Alat Tangkap dan Life Jacket

\section{SIMPULAN DAN TINDAK LANJUT}

Pemilihan pengabdian masyarakat pembuatan alat penangkap ikan ramah lingkungan merupakan bentuk kepedulian Politeknik KP Sorong sebagai perguruan tinggi bidang kelautan dan perikanan akan upaya sinergitas program pemerintah daerah menjadikan Papua Barat sebagai provinsi konservasi. Perannya juga membantu masyarakat meningkatkan kesejahteraanya memperoleh potensi ekonomi dengan menggunakan alat tangkap ramah lingkungan. 
Solusi yang diberikan oleh tim pengabdi yakni memberikan materi perikanan ramah lingkungan, praktik membuat alat tangkap ramah lingkungan Gillnets dan pancing cumi, praktik pengoperasian Gillnets dan pancing cumi, dan perbaikan dan perawatan Gillnets dan pancing cumi. Materi tambahan diberikan keselamatan dasar nelayan sebagai bekal nelayan dalam menghadapai kecelakaan maupun preventif terhadap kejadian di laut.

Evaluasi dilakukan oleh tim pengabdi untuk mengetahui sejauh kemampuan melakukan praktik program pengabdian yang telah dilaksanakan. Hasil evaluasi seluruh peserta mampu mengikuti arahan tim pengabdi dan instruktur dengan hasil alat tangkap yang diselesaikan diberikan kepada mitra sasaran untuk dapat dipergunakan menangkap ikan. Pengabdian masyarakat berikutnya akan diberikan alternatif usaha penangkapan ikan berupa kegiatan budidaya.

\section{UCAPAN TERIMA KASIH}

Ucapan terima kasih disampaikan kepada Direktur Politeknik KP Sorong yang telah menyetujui anggaran dan lokasi pelaksanaan kegiatan pengabdian masyarakat di Kelurahan Saoka. Terima kasih atas upaya yang besar dan saran yang diberikan oleh Kepala Pusat Penelitian dan Pengabdian Masyarakat, Dr. Ismail, sehingga kegiatan ini memberikan dampak bagi peningkatan kualitas pengabdian masyarakat. Terima kasih atas bantuan Lurah Saoka atas koordinasi yang baik sehingga kegiatan terlaksana dengan baik.

\section{DAFTAR RUJUKAN}

Amin, M., Purwangka, F., \& Mawardi, W. (2018). Tingkat Keterampilan dan Pengetahuan Nelayan Di Karangantu Banten. ALBACORE, 2(1).

Bubun, R. L., \& Anwar, L. O. (2016). Penyuluhan Dampak Metode Penangkapan Ikan Destructive Terhadap Perikanan Berkelanjutan. Research Report, 125-132.

Dewanti, L. P. (2018). Prinsip Penangkapan Ikan Ramah Lingkungan Kepada Kelompok Nelayan Dalam Upaya Perikanan Berkelanjutan Di Kabupaten Pangandaran. Jurnal Pengabdian Kepada Masyarakat, 2(10), 891-894.

Gray, N. J. (2010). Sea change: exploring the international effort to promote marine protected areas. Conservation and Society, 8(4), 331-338.

Hendrawan, A. (2017). Analisa Keselamatan dan Kesehatan Kerja pada Nelayan. Saintara: Jurnal Ilmiah Ilmu-Ilmu Maritim, 2(1), 12-23.

Imron, M., Nurkayah, R., \& Purwangka, F. (2017). Pengetahuan dan Keterampilan Nelayan Tentang Keselamatan Kerja di PPP Muncar, Banyuwangi. ALBACORE Jurnal Penelitian Perikanan Laut, 1(1), 99-109.

Jompa, J., Malina, A. C., Rahmi, R., Anwar, A., \& Arifah, A. N. (2018). PROGRAM KEMITRAAN WILAYAH (PKW) DIKECAMATAN LIUKANG TUPABBIRING UTARA KABUPATEN PANGKEP. Ngayah: Majalah Aplikasi IPTEKS, 9(2), 187-204.

Kaim, M. A., Tamarol, J., \& Kumaseh, E. (2017). IbM Pengenalan Alat Tangkap Bubu Rangka Besi untuk Menangkap Kepiting di Kampung Beeng. Jurnal Ilmiah Tatengkorang, 1, 29-32.

Lampe, M., Demmalino, E. B., Neil, M., \& Jompa, J. (2017). Main Drivers And Alternative Solutions For Destructive Fishing In South Sulawesi-Indonesia: Lessons Learned From Spermonde Archipelago, Taka Bonerate, And Sembilan Island. Sci. Int. Lahore, 29, 159-167.

Martinet, V., Peña-Torres, J., De Lara, M., \& Ramírez, H. (2016). Risk and sustainability: Assessing fishery management strategies. Environmental and Resource Economics, 64(4), 683-707.

Mujiman, H. (2006). Belajar Mandiri (Self Motivation Learning). Cetakan. 
Mussadun, M., Fahrudin, A., Kusumastanto, T., \& Kamal, M. M. (2016). Analisis Persepsi Nelayan Dalam Pengelolaan Sumberdaya Perikanan Berkelanjutan Di Taman Nasional Karimunjawa1. TATALOKA, 13(2), 70-81.

Papua Barat, P. perdasus_nomor_10_tahun_2019_(pembangunan_berkelanjutan_di_provinsi_papua_barat)_3. $p d f$.

Ratri, C. P., \& Paskarini, I. (2014). Faktor yang Berhubungan dengan Kejadian Scabies pada Nelayan di Desa Weru Kecamatan Paciran Kabupaten Lamongan. The Indonesian Journal of Occupational Safety, Health and Environment, 1(1), 132-143.

Republik, P. M. K. D. P. (2017). Indonesia [PERMEN-KP] No. 71 Tahun 2016. Diakses.

Santosa, A. W. B., Iqbal, M., Mulyatno, I. P., Sisworo, S. J., Budiarto, U., \& Rindo, G. (2019). PEMBERDAYAAN NELAYAN TANGKAP TRADISIONAL MELALUI PENGGUNAAN ALAT BANTU PENGUMPUL IKAN RAMAH LINGKUNGAN. Jurnal Pasopati, 1(1).

Statistik, B. P. (2019). Kecamatan Maladum Mes dalam Angka.

Subehi, S., Boesono, H., \& Dewi, D. A. N. N. (2017). Analisis alat penangkap ikan ramah lingkungan berbasis code of conduct for responsible fisheries (CCRF) di TPI Kedung Malang Jepara. Journal of Fisheries Resources Utilization Management and Technology, 6(4), $1-20$.

Sumardi, Z., Sarong, M. A., \& Nasir, M. (2014). Alat penangkapan ikan yang ramah lingkungan berbasis code of conduct for responsible fisheries di Kota Banda Aceh. Jurnal Agrisep, 15(2), 10-18.

Sutrisno, A., Syofyan, I., \& Isnaniah, I. (2014). Study Construction of Gillnet In The Village Nipah Panjang 1, Subdistrict of Nipah Panjang, East Tanjung Jabung Regency, Province of Jambi. Riau University. 